\title{
Index to Volume 70
}

Adamczewski, J. (See Kutz, S.)

Adams, P. (Book Review) Two Years Below the Horn: Operation Tabarin, Field Science, and Antarctic Sovereignty, 1944-1946, by Andrew Taylor; edited by Daniel Heidt and P. Whitney Lackenbauer. 70(4):425-426.

Aleuy, O.A. (See Kutz, S.)

Andersen, A.O. (See Heide-Jørgensen, M.P.)

Arnfjord, S. (See Christensen, J.)

Atkinson, D.E. (See Eerkes-Medrano, L.)

Austin, M. (See Kutz, S.)

Ayre, M. (Book Review) Scottish Arctic Whaling, by Chesley W. Sanger. 70(2):219-220.

Berger, J. (See Kutz, S.)

Blake, J. (See Kutz, S.)

Bondo, K. (See Kutz, S.)

Branigan, M. (See Pongracz, J.D.)

Bringloe, T.T., Dunton, K.H., and Saunders, G.W. Updates to the Marine Algal Flora of the Boulder Patch in the Beaufort Sea off Northern Alaska as Revealed by DNA Barcoding. 70(4):343-348.

Bröker, K. (See Frouin-Mouy, H.)

Brower, H. (See Harwood, L.A.)

Brown, T.A. (See Forst, J.)

Brown, W.A. (See Tremayne, A.H.)

Carraher, S. (See Christensen, J.)

Cavell, J. The Sea of Ice and the Icy Sea: The Arctic Frame of Frankenstein. 70(3):295-307.

- (Book Review) Lines in the Ice: Exploring the Roof of the World, by Philip Hatfield. 70(4):426-427.

Chan, H.M. (See Kenny, T.-A.)

Christensen, J., Arnfjord, S., Carraher, S., and Hedwig, T. Homelessness across Alaska, the Canadian North and Greenland: A review of the Literature on a Developing Social Phenomenon in the Circumpolar North. 70(4):349-364.

Christie, K.S. (See Solovyeva, D.V.)

Clarke, J. (See Lowry, L.F.)

Cuyler, C. (See Kutz, S.)

Dalton, C. (See Kutz, S.)

Davis, L.E., and Davison, C.M. Prevalence and Patterns of SugarSweetened Beverage Consumption in Canadian Youth: A Northern Focus. 70(4):414-424.

Davison, C.M. (See Davis, L.E.)

Day, R.H., Prichard, A.K., Rose, J.R., Streever, B., and Swem, T. Effects of a Hazing-Light System on Migration and Collision Avoidance of Eiders at an Artificial Oil-Production Island, Arctic Alaska. 70(1):13-24.

De Jong, T. (See Insley, S.J.)

Derocher, A.E. (See Johnson, A.C.) (See Yee, M.)

Di Francesco, J. (See Kutz, S.)

Dietz, R. (See Leerhøi, F.)

Dobson, A. (See Kutz, S.)

Dunton, K.H. (See Bringloe, T.T.)
Eerkes-Medrano, L., Atkinson, D.E., Eicken, H., Nayokpuk, B., Sookiayak, H., Ungott, E., and Weyapuk, W., Jr. Slush-Ice Berm Formation on the West Coast of Alaska. 70(2):190-202.

Eicken, H. (See Eerkes-Medrano, L.)

Erwin, J.C. (Book Review) The Frozen Saqqaq Sites of Disko Bay, West Greenland: Qeqertasussuk and Qajaa (2400-900 BC), Studies of Saqqaq Material Culture in an Eastern Arctic Perspective, by Bjarne Grønnow. 70(4):427-428.

Fall, J.A. (See Naves, L.C.)

Finney, B. (See Loso, M.)

Flora, J. (See Heide-Jørgensen, M.P.)

Forst, J., and Brown, T.A. A Case Study: Was Private William Braine of the 1845 Franklin Expedition a Victim of Tuberculosis? 70(4):381-388.

Frisch, T. (Obituary) James William Kerr (1936-2017). 70(3):332-333.

Frouin-Mouy, H., Kowarski, K., Martin, B., and Bröker, K. Seasonal Trends in Acoustic Detection of Marine Mammals in Baffin Bay and Melville Bay, Northwest Greenland. 70(1):59-76.

Gabrielson, M. (See Solovyeva, D.V.)

Galloway, T. (See Widener, M.J.)

George, J.C., Sheffield, G., Reed, D.J., Tudor, B., Stimmelmayr, R., Person, B.T., Sformo, T., and Suydam, R. Frequency of Injuries from Line Entanglements, Killer Whales, and Ship Strikes on Bering-Chukchi-Beaufort Seas Bowhead Whales. 70(1):37-46.

George, J.C. (See Harwood, L.A.)

Gerlach, C. (See Kutz, S.)

Greenberg, J. (See Starr, L.)

Gross, T. (See Taichman, R.S.)

Gundersen, V. (See Kaltenborn, B.P.)

Gunn, A. (See Kutz, S.)

Halliday, W.D. (See Insley, S.J.)

Hansen, R.G. (See Heide-Jørgensen, M.P.)

Harington, C.R. (See Holen, S.R.)

Harwood, L.A., Quakenbush, L.T., Small, R.J., George, J.C., Pokiak, J., Pokiak, C., Heide-Jørgensen, M.P., Lea, E.V., and Brower, H. Movements and Inferred Foraging by Bowhead Whales in the Canadian Beaufort Sea during August and September, 2006-12. 70(2):161-176.

Hauser, D.D.W. (See Lowry, L.F.)

Hedwig, T. (See Christensen, J.)

Heide-Jørgensen, M.P., Flora, J., Andersen, A.O., Stewart, R.E.A., Nielsen, N.H., and Hansen, R.G. Walrus Movements in Smith Sound: A Canada-Greenland Shared Stock. 70(3):308-318.

Heide-Jørgensen, M.P. (See Harwood, L.A.)

Holen, K.A. (See Holen, S.R.)

Holen, S.R., Harington, C.R., and Holen, K.A. New Radiocarbon Ages on Percussion-Fractured and Flaked Proboscidean Limb Bones from Yukon, Canada. 70(2):141-150. 
Insley, S.J., Halliday, W.D., and de Jong, T. Seasonal Patterns in Ocean Ambient Noise near Sachs Harbour, Northwest Territories. 70(3):239-248.

Ives, J.D. (Book Review) Vatnajökull National Park (Southern Region): Guide to a Glacial Landscape Legacy, by David J.A. Evans. 70(2):220-221.

Johnson, A.C., Pongracz, J.D., and Derocher, A.E. Long-Distance Movement of a Female Polar Bear from Canada to Russia. 70(2):121-128.

Johnson. R. (See Loso, M.)

Kafle, P. (See Kutz, S.)

Kaltenborn, B.P., Mehmetoglu, M., and Gundersen, V. Linking Social Values of Wild Reindeer to Planning and Management Options in Southern Norway. 70(2):129-140.

Kenny, T.-A., and Chan, H.M. Estimating Wildlife Harvest Based on Reported Consumption by Inuit in the Canadian Arctic. 70(1):1-12.

Kingsley, M.C.S. (See Lowry, L.F.)

Kokhanova, V.Yu. (See Solovyeva, D.V.)

Kowarski, K. (See Frouin-Mouy, H.)

Kutz, S., Rowell, J., Adamczewski, J., Gunn, A., Cuyler, C., Aleuy, O.A., Austin, M., Berger, J., Blake, J., Bondo, K., Dalton, C., Dobson, A., Di Francesco, J., Gerlach, C., Kafle, P., Mavrot, F., Mosbacher, J., Murray, M., Nascou, A., Orsel, K., Rossouw, F., Schmidt, N.-M., Suitor, M., Tomaselli, M., and Ytrehus, B. (InfoNorth) Muskox Health Ecology Symposium 2016: Gathering to Share Knowledge on Umingmak in a Time of Rapid Change. 70(2):225-236.

Lantz, T.C. Vegetation Succession and Environmental Conditions following Catastrophic Lake Drainage in Old Crow Flats, Yukon. 70(2):177-189.

Lea, E.V. (See Harwood, L.A.)

Leerhøi, F., Dietz, R., Sonne, C., and Lorenzen, E.D. (InfoNorth) The Danish Polar Bear Skull Collection 1830-2016. 70(3):334-340.

Ljubicic, G., Oberndorfer, E., and Smith, G. (InfoNorth) The Curious Case of King William Island, Nunavut: An Island Overlooked in Caribou Research. 70(1):107-117.

Ljubicic, G.J. (Book Review) "The Caribou Taste Different Now": Inuit Elders Observe Climate Change, edited by José Gérin-Lajoie, Alain Cuerrier, and Laura Siegwart Collier. 70(1):102-104.

Lorenzen, E.D. (See Leerhøi, F.)

Loso, M., Finney, B., Johnson, R., and Sinnott, R. Evaluating Evidence for Historical Anadromous Salmon Runs in Eklutna Lake, Alaska. 70(3):259-272.

Lowry, L.F., Kingsley, M.C.S., Hauser, D.D.W., Clarke, J., and Suydam, R. Aerial Survey Estimates of Abundance of the Eastern Chukchi Sea Stock of Beluga Whales (Delphinapterus leucas) in 2012. 70(3):273-286.

Lunn, N.J. (See Yee, M.)

MacEachern, M.P. (See Taichman, R.S.)

Martin, B. (See Frouin-Mouy, H.)
Mavrot, F. (See Kutz, S.)

McCall, A.G. (See Yee, M.)

McKnight, E. (InfoNorth) Characterizing and Monitoring the Water Properties and Dynamics of Lhù'ààn Män (Kluane Lake), Yukon, in the Face of Climate Change. 70(4):435-440.

Mehmetoglu, M. (See Kaltenborn, B.P.)

Melnikov, V.V. Seasonal Movements and Relative Abundance of Bearded Seals (Erignathus barbatus) in the Coastal Waters of the Chukotka Peninsula. 70(4):403-413.

Millar, D. (Book Review) A Farewell to Ice: A Report from the Arctic, by Peter Wadhams. 70(1):101-102.

Millman, L. (Book Review) An Intimate Wilderness: Arctic Voices in a Land of Vast Horizons, by Norman Hallendy. 70(1):101.

- (Book Review) Imagining the Supernatural North, edited by Eleanor Rosamund Barraclough, Danielle Marie Cudmore and Stefan Donecker. 70(3):328.

Mosbacher, J. (See Kutz, S.)

Murray, M. (See Kutz, S.)

Nascou, A. (See Kutz, S.)

Naves, L.C., and Fall, J.A. Calculating Food Production in the Subsistence Harvest of Birds and Eggs. 70(1):86-100.

Nayokpuk, B. (See Eerkes-Medrano, L.)

Nielsen, N.H. (See Heide-Jørgensen, M.P.)

Oberndorfer, E. (See Ljubicic, G.)

Orsel, K. (See Kutz, S.)

Paetkau, D. (See Pongracz, J.D.)

Park, R.W. (Book Review) Finding Franklin: The Untold Story of a 165-Year Search, by Russell A. Potter. 70(1):104-105. - (See Stenton, D.R.)

Peers, M.J.L. (InfoNorth) Predicting the Fitness Effects of Climate Change on Snowshoe Hares. 70(4):430-434.

Person, B.T. (See George, J.C.)

Peterson, A. (See Yang, D.)

Pilfold, N.W. (See Yee, M.)

Pokiak, C. (See Harwood, L.A.)

Pokiak, J. (See Harwood, L.A.)

Pongracz, J.D., Paetkau, D., Branigan, M., and Richardson, E. Recent Hybridization between a Polar Bear and Grizzly Bears in the Canadian Arctic. 70(2):151-160.

Pongracz, J.D. (See Johnson, A.C.)

Prichard, A.K. (See Day, R.H.)

Quakenbush, L.T. (See Harwood, L.A.)

Rack, U. (Book Review) Carl Weyprecht and the International Polar Years, by Enrico Mazzoli. 70(2):221 - 222.

Reed, D.J. (See George, J.C.)

Reimer, J. (See Yee, M.)

Richardson, E. (See Pongracz, J.D.)

Rose, J.R. (See Day, R.H.)

Rossouw, F. (See Kutz, S.)

Rowell, J. (See Kutz, S.)

-. (See Starr, L.) 
Saunders, G.W. (See Bringloe, T.T.)

Saxe, S. (See Widener, M.J.)

Schmidt, N.-M. (See Kutz, S.)

Sformo, T. (See George, J.C.)

Sheffield, G. (See George, J.C.)

Sinnott, R. (See Loso, M.)

Small, R.J. (See Harwood, L.A.)

Smith, G. (See Ljubicic, G.)

Solovyeva, D.V., Kokhanova, V.Yu., Gabrielson, M., and Christie, K.S. Testing for Geographic Variation in Survival of Spectacled Eider (Somateria fischeri) Populations in Chukotka, Russia and the Yukon-Kuskokwim Delta, Alaska. 70(3):287-294.

Sonne, C. (See Leerhøi, F.)

Sookiayak, H. (See Eerkes-Medrano, L.)

Starr, L., Greenberg, J., and Rowell, J. Farming Muskoxen for Qiviut in Alaska: A Feasibility Study. 70(1):77-85.

Stenton, D.R., and Park, R.W. History, Oral History and Archaeology: Reinterpreting the "Boat Places" of Erebus Bay. 70(2):203-218.

Stewart, R.E.A. (See Heide-Jørgensen, M.P.)

Stimmelmayr, R. (See George, J.C.)

Stirling, I. (Book Review) Ice Bear: The Cultural History of an Arctic Icon, by Michael Engelhard. 70(3):329-330.

Streever, B. (See Day, R.H.)

Strong, W.L. Episodic and Systematic Tree Ring-Width Variation (AD 1763-2013) in the Takhini Valley, Southwest Yukon, Canada. 70(4):389-402.

Suitor, M. (See Kutz, S.)

Suydam, R. (See George, J.C.)
(See Lowry, L.F.)

Swem, T. (See Day, R.H.)

Taichman, R.S., Gross, T., and MacEachern, M.P. A Critical Assessment of the Oral Condition of the Crew of the Franklin Expedition. 70(1):25-36.

Togunov, R.R. (See Yee, M.)

Tomaselli, M. (See Kutz, S.)

Tremayne, A.H., and Brown, W.A. Mid to Late Holocene Population Trends, Culture Change and Marine Resource Intensification in Western Alaska. 70(4):365-380.

Tudor, B. (See George, J.C.)

Ungott, E. (See Eerkes-Medrano, L.)

Way, L. (Book Review) Care, Cooperation and Activism in Canada's Northern Social Economy, edited by Frances Abele and Chris Southcott. 70(2):222-223.

Weyapuk, W., Jr. (See Eerkes-Medrano, L.)

Widener, M.J., Saxe, S., and Galloway, T. The Relationship between Airport Infrastructure and Flight Arrivals in Remote Northern Canadian Communities. 70(3):249-258.

Yang, D., and Peterson, A. River Water Temperature in Relation to Local Air Temperature in the Mackenzie and Yukon Basins. 70(1):47-58.

Yee, M., Reimer, J., Lunn, N.J., Togunov, R.R., Pilfold, N.W., McCall, A.G., and Derocher, A.E. Polar Bear (Ursus maritimus) Migration from Maternal Dens in Western Hudson Bay. 70(3):319-327.

Ytrehus, B. (See Kutz, S.) 